\title{
Helping Babies Breathe (HBB) Program for Reduction of Neonatal Mortality: A Hospital Based Cost Effective Intervention in Nepal
}

\author{
Kanchan Thapa', Robert B. Clark', Michael K. Visick', Yubanidhi Basaula ${ }^{4}$, Rakesh Hamal \\ and Naresh Pratap $\mathrm{KC}^{1}$
}

${ }^{1}$ Safa Sunaulo Nepal, Kathmandu, Nepal

${ }^{2}$ Department of Public Health, Brigham Young University, Provo, Utah, USA

${ }^{3}$ Department of Pediatrics, University of Utah School of Medicine, Utah, USA

${ }^{4}$ Bharatpur Hospital, Ministry of Health and Population (MoHP), Government of Nepal

\section{INTRODUCTION}

Helping Babies Breathe (HBB $)^{1}$ is an evidencebased curriculum being used worldwide to teach neonatal resuscitation skills. The intervention is particularly famous for saving the lives of neonates in low resource countries. ${ }^{2}$ Nepal has high neonatal and maternal mortality rate in Asia. ${ }^{3}$ HBB is a key interventions to reduce neonatal mortality through the management of birth asphyxia. It focuses on action within the "golden minute," referring to appropriate resuscitation in the first 60 seconds of life.

Latter-day Saint Charities (LDSC), an international humanitarian non-governmental agency from United States, ${ }^{4}$ is responsible for HBB program introduction and implementation in Nepal. Safa Sunaulo Nepal (SSN) in close coordination with National Health Training Centre (NHTC) has been implementing the program in hospitals of Nepal. ${ }^{5}$

Nepal has more than seven years of HBB program experience since its introduction in 2012 in
Kathmandu. A large-scale study at Paropakar Maternity Hospital of Kathmandu proved that it is one of the most effective interventions for neonatal death reduction in Nepal. It also reduced the still birth rate which had been previously over reported. ${ }^{6}$

Nepal aims to reduce the neonatal mortality to less than 12 per thousand live births by $2030 .^{7}$ It has just been able to reach 21 per thousand live births. ${ }^{3}$ There is yet a very long journey to meet the SDG target. Therefore, the success story of HBB program implementation can be a leading intervention to fulfil the goal. In order to improve both maternal and newborn health, HBB has been combined with Helping Mothers Survive (HMS) ${ }^{8}$ curriculum since 2018. The HMS module, Bleeding After Birth aims to reduce the rate of post-partum haemorrhage $(\mathrm{PPH})$. Since it is one of the leading causes of maternal death in Nepal. ${ }^{9}$

Correspondence: Kanchan Thapa, Safa Sunaulo Nepal, Kathmandu, Nepal. Email: kanchanraj3@gamil.com

DOI: http://dx.doi.org/10.3126/mjsbh.v19i1.25961

Submitted on: 2019-10-17

Accepted on: 2019-12-01

This work is licensed under creative common license:

http://creativecommons.org/licenses/by-nc-nd/4.0/ C MJSBH 2020 


\section{METHODS}

Training, program supervision and monitoring activities have been conducted by LDSC and SSN in close coordination with NHTC. Public health facilities have been supplied with training equipment and educational materials for teaching providers as well as trainers. A pair of trainers from each selected health facility is first trained as Master Trainers and then provide a one-day training course to their peers at their facility. This training cascade reduces the travel time and cost of training.

To date, HBB training courses have been widely practiced through midwifery education, SBA, advanced SBA and nursing education in Nepal. As per the record of SSN for 2019, we have already trained more than seven hundred Master Trainers in Nepal. ${ }^{5}$

In order to provider supportive supervision to providers, monitors and mentors have been allocated, with each assigned to about 15 hospitals. Currently there are four monitors covering more than 70 health institutions of Nepal and mentoring master trainers in teaching HBB courses to program hospitals. Medical and nursing colleges have been teaching HBB and our program monitors have been supporting them.

\section{CHALLENGES}

The program's greatest challenge is due to shortage, transfer, and retention of staffs. It is one of the major problems in health system quality of Nepal. Another challenge is inadequate space in labor and delivery wards with difficulty in designating skills practice corner or holding classes.

The quality of reported data is another concern. Throughout the country, hospitals have been lacking standard recording and reporting forms. So, some of the information has been missing.

In medical colleges, they have often taught advanced neonatal resuscitation procedures that are rarely needed, with the unintended consequence of making basic resuscitation appear too simple and unnecessary to practice.

\section{RECOMMENDATIONS}

For sustaining the change, there should be regular supportive supervision and monitoring from concerned agencies. The hospitals should have standardised reporting formats throughout the country. The hospital maternal and perinatal death steering review (MPDSR) committee should be active. The hospital authorities should be more responsible for recognising the role of HBB in their hospital quality improvement. Qualitative research exploring the challenges, pros and cons of the program is also recommended. The role of development partners is deemed essential for some more years in order to sustain the change.

\section{CONCLUSIONS}

At present, the current HBB program is successful in teaching neonatal resuscitation and saving lives in Nepal. Continued efforts are required in order to sustain the change. The educational materials have been already adopted by medical universities and colleges. Health workers should be mentored and practice their skills regularly in order to retain their skills and quality improvement. The goal of reduction of neonatal mortality seems to be possible through HBB implementation.

\footnotetext{
To cite this article: Thapa K, Clark RB, Visick MK, Basaula Y, Hamal R, KC NP. Helping Babies Breath (HBB) Program for reduction of Neonatal mortality: A hospital based Cost Effective Intervention in Nepal. MJSBH. 2019;19(1):48-50.
}

Conflict of Interest: None declared 


\section{REFERENCES}

1. American Academy of Pediartics (AAP). Helping Babies Breathe. Helping Babies Breathe 2nd Edition. 2015. Available from: https:/www.aap.org/en-us/advocacy-and-policy/aap-health-initiatives/helping-babies-survive/ Pages/Helping-Babies-Breathe.aspx

2. Eblovi D, Kelly P, Afua G, Agyapong S, Dante S, Pellerite M. Retention and use of newborn resuscitation skills following a series of helping babies breathe trainings for midwives in rural Ghana. Glob Health Action. 2017;10(1). DOI: https://doi.org/10.1080/16549716.2017.1387985

3. Ministry of Health Nepal. Nepal Demographic Health Survey (NDHS) Report 2016. Available from: https:/www.dhsprogram.com/pubs/pdf/FR336/FR336.pdf

4. Latter-day Saint Charities. About Us. 2018 [cited 2019 Oct 26].

Available from: https://www.latterdaysaintcharities.org/

5. Safa Sunaulo Nepal. Report of Safa Sunaulo Nepal. 2019.

6. Kc A, Wrammert J, Clark RB, Ewald U, Vitrakoti R, Chaudhary P, et al. Reducing perinatal mortality in Nepal using helping babies breathe. Pediatrics. 2016;137(6).

DOI: $10.1542 /$ peds.2015-0117

7. National Planning Commission Nepal. Sustainable Development Goals. Sustainable Development Goals, 2016-2030, National (Preliminary) Report. Government of Nepal, National Planning Commission, Kathmandu, Nepal. 2015.

Available from: http://www.biomedcentral.com/1471-2393/14/282

8. Jhpiego. Helping Mother Survive- Training and Programming Materials. 2019.

Available from: https:/hms.jhpiego.org/training-materials/

9. Pathak LR, Kwast BE, Malla DS, Pradhan AS, Rajlawat R, Campbell BB. Process indicators for safe motherhood programmes: their application and implications as derived from hospital data in Nepal. Trop Med Int Health. 2000;5(12):882-90.

DOI: $10.1046 / \mathrm{j} .1365-3156.2000 .00662 . x$ 